\title{
Social-ecological systems as complex adaptive systems: organizing principles for advancing research methods and approaches
}

\author{
$\underline{\text { Rika Preiser }}^{1}, \underline{\text { Reinette Biggs }}^{1,2}, \underline{\text { Alta De Vos }}^{3}$ and Carl Folke $^{2,4}$
}

\begin{abstract}
The study of social-ecological systems (SES) has been significantly shaped by insights from research on complex adaptive systems (CAS). We offer a brief overview of the conceptual integration of CAS research and its implications for the advancement of SES studies and methods. We propose a conceptual typology of six organizing principles of CAS based on a comparison of leading scholars' classifications of CAS features and properties. This typology clusters together similar underlying organizing principles of the features and attributes of CAS, and serves as a heuristic framework for identifying methods and approaches that account for the key features of SES. These principles can help identify appropriate methods and approaches for studying SES. We discuss three main implications of studying and engaging with SES as CAS. First, there needs to be a shift in focus when studying the dynamics and interactions in SES, to better capture the nature of the organizing principles that characterize SES behavior. Second, realizing that the nature of the intertwined social-ecological relations is complex has real consequences for how we choose methods and practical approaches for observing and studying SES interactions. Third, engagement with SES as CAS poses normative challenges for problemoriented researchers and practitioners taking on real-world challenges.
\end{abstract}

Key Words: complex adaptive systems; normative implications; ontology; social-ecological systems; typology of systemic features and dynamics

\section{INTRODUCTION}

Navigating the environmental and societal challenges that mark the new geological era of the Anthropocene (Steffen et al. 2011, 2018) pose major challenges to researchers, policy makers, and civil society organizations because they are becoming increasingly dependent on research and practice-orientated approaches that render a deepened understanding of the nature and implications of the dynamic interactions that link ecosystems and human societies (Folke et al. 2016). Major research programs that study global environmental change processes and sustainable human development pathways such as Future Earth (Rockström 2016), and policy frameworks such as the Sustainable Development Goals (Díaz et al. 2015, Fischer et al. 2015) allude to the fact that these challenges are best tackled from a complex adaptive systems (CAS) perspective (Levin et al. 2013, Reyers et al. 2018). For a new generation of students and practitioners entering this field, CAS research might seem to be a readily available, coherent, and well-established body of knowledge for investigating socialecological systems (SES) behavior. In reality, however, finding one's way through the theories and concepts that constitute CAS research is often a challenging journey (Haider et al. 2018). Furthermore, the implications of CAS for identifying which aspects and features of SES to research, and understanding what methods and approaches are suited to studying these features, as well as considering the ethical implications of a CAS approach, are generally under appreciated.

To date, the conceptual framing of SES as CAS has substantially supported the recognition that human systems and ecosystems are inextricably linked (Berkes et al. 2003, Díaz et al. 2006, Summers et al. 2012, Wu 2013). Moreover, this approach has emerged as a significant field of research for understanding the relations and feedbacks that shape the dynamics and features of SES (Carpenter et al. 2012, Fischer et al. 2015). CAS concepts such as critical thresholds, tipping points, regime shifts (Carpenter 2003, Folke et al. 2011, Westley et al. 2011, Scheffer et al. 2012, Hughes et al. 2013), cross-scale linkages, feedback loops, and nonlinearities (Gunderson and Holling 2002, Walker et al. 2006, Biggs et al. 2012) are widely used to identify and explain the complex nature and associated patterns of SES behavior. The integration of CAS concepts into SES research is also demonstrated by the frameworks conceptualizing SES and principles (Ostrom 2009, Crepin et al. 2012, Biggs et al. 2015a). However, there has been limited systematic reflection on the implications of CAS understanding for identifying relevant methods and practical approaches to studying SES, and the normative implications of CAS-based applications for SES research (Biggs et al. 2015b, Reyers et al. 2015).

In this paper, we aim to provide an entry point to researchers, decision makers, and social entrepreneurs who want to operationalize CAS-based approaches in the study of SES. Thus, this paper sets out to accomplish the following:

1. Give a brief overview of how the theoretical developments in CAS studies influenced SES research to the extent that it is now commonly accepted that SES are perceived to be CAS (Berkes and Folke 1998, Norberg 2004, Levin 2005, Schoon and van der Leeuw 2015, Hagstrom and Levin 2017);

2. Offer a conceptual typology of the defining attributes of CAS that provides a heuristic framework to guide the operationalization of CAS thinking. This typology clusters different types of attributes and properties with similar underlying causal explanations that organize part-whole relations and thus, bring systems into being. This conceptual typology aims to facilitate reflection of the practical implications of CAS-based approaches, and assessment of methods for studying, understanding, and governing CAS;

${ }^{1}$ Centre for Complex Systems in Transition, Stellenbosch University, South Africa, ${ }^{2}$ Stockholm Resilience Centre, Stockholm University, Sweden, ${ }^{3}$ Department of Environmental Science, Rhodes University, South Africa, ${ }^{4}$ Beijer Institute, Royal Swedish Academy of Sciences, Sweden 
3. Equip scholars in the field of SES research with a deeper understanding as to why CAS-based approaches are different to conventional disciplinary approaches; why it matters; and what the implications are for methods and approaches in SES research.

\section{FROM SYSTEMS TO COMPLEX ADAPTIVE SOCIAL- ECOLOGICAL SYSTEMS}

Since von Bertalanffy's (1968) first conceptual formulation of an overarching framework for understanding the organizing principles of living systems, the notion of system and the approach of systems thinking have both enjoyed widespread application in a variety of disciplines. The field of systems theory and practice developed in the mid-20th century as a response to the limitations of traditional scientific approaches that studied the behavior of living systems in terms of mechanistic and reductionist assumptions (Hammond 2017). Seeking to understand the nature of natural systems, Meadows (2008:2) argues that a system comprises "a set of things - people, cells, molecules, or whatever - interconnected in such a way that they produce their own pattern of behavior over time." This basic description of a system suggests that through the dynamic interactions between interconnected parts, systemic properties emerge that cause systems to produce and maintain their own patterns of behavior over time. Furthermore, the interlinked parts of systems produce effects that are different from those of the individual parts.

The notion of complexity, seen as a systems property, expands on the ideas of systems thinking, and has been studied from a variety of perspectives (Bateson 1979, Prigogine and Stengers 1984, Rosen 1991, Holland 1995, Cilliers 1998, Arthur 1999, Levin 1999, Morin 2008). The terms complexity science and complexity theory are often used interchangeably with complex adaptive systems or even complexity. Despite this conceptual and semantic diversity, the concepts and ideas that inform theories of complexity have informed a wide range of disciplines (Midgley 2006, Cairney 2012, Boulton et al. 2015, Jörg 2017). Some authors suggest that a prolific uptake and assimilation of concepts and terminology has led to a "complexity turn" (Urry 2005), which could eventually lead to a "paradigmatic turning point" (Morin 2008).

The widespread contemporary use of the term complexity might suggest that a unified theory of complexity exists; however, this is not the case (Thrift 1999, Chu et al. 2003). A closer investigation reveals that multiple interpretations and lineages from various disciplines inform definitions of the notion of complexity (Morin 2008, Woermann 2016). Nevertheless, a general and overarching understanding, as well as vocabulary, of complexity has emerged that is woven together by several different theories of complexity (Rasch 1991, Chu et al. 2003, Alhadeff-Jones 2013), drawn from a range of different fields of study ${ }^{[1]}$.

The adoption and integration of this hybrid body of knowledge called complexity theory in SES research has had far-reaching effects in shaping this new interdisciplinary field of study (Schoon and van der Leeuw 2015). The fundamental tenets of SES research are based on the understanding that linked human and ecological systems are CAS (Günther and Folke 1993, Berkes and Folke 1998, Holling 2001, Folke et al. 2004, 2016, Levin et al. 2013, Liu et al. 2007, Rogers et al. 2013). This positioning forms the implicit conceptual point of departure for SES research (Bodin and Tengö 2012, Binder et al. 2013, Cumming 2014, Schlüter et al. 2014, Schoon and van der Leeuw 2015). The definitions of SES related concepts such as resilience, adaptability, transformability, and stewardship are all informed by the underlying assumptions that inform our understanding of the characteristics and dynamics of CAS (Folke et al. 2004, 2016, Walker et al. 2004, Levin et al. 2013). Moreover, these assumptions have shaped the methods, theories, and research approaches in the field of SES research and deeply inform resilience thinking (Folke 2016), which has become a prominent framework for understanding how change, adaptation, and transformation are navigated in SES.

A brief overview of the place of complexity in the historical development of SES, however, shows that this was not always the case. In summarizing the development of the concept of resilience, Folke $(2006,2016)$ explains how early work during the 1980s in the field of adaptive ecosystem management, initially relied on dynamical systems theory to argue in favor of more dynamic models to analyze ecosystem structures and behavior. This was an attempt to understand how institutions and the people associated with them should be organized and managed. However, during the 1990s, a series of publications introduced the idea that ecological systems should be reframed as being complex and adaptive in nature.

In a special landmark edition of the journal Ecosystems (1998), Hartvigsen et al. (1998) argued that although systems theory had been widely applied in the field of ecology, the analytical limitations of traditional systems approaches meant that the influence of processes of adaptation in ecosystem dynamics had been overlooked. By characterizing ecosystem dynamics as complex adaptive systems (and not only as complex systems), researchers were given the tools to incorporate variability (biodiversity) and adaptation in analyses of ecosystem interaction. This led to a better understanding of how "patterns and processes emerge and interact across levels of biological organization, and across spatial and temporal scales" (Hartvigsen et al. 1998:428). In the same edition, Levin (1998) and Milne (1998) respectively argue that insights from complexity studies could be very useful in understanding why and how ecological systems could simultaneously maintain diversity and individuality of components and what kinds of effects this dynamic interaction has on the generation of novelty and the overall development of the system.

The terms systems, complexity, and CAS are often used interchangeably, but CAS should be perceived as a special instance of systems. This understanding, therefore, extends the definition of traditional systems theory by recognizing that CAS contain adaptive components and capacities. Adaptive components allow systems to change and evolve over time in response to feedbacks and changes in the system context. This means that CAS have a memory and the capacity to learn from previous responses and configurations and thus, influence and shape current and future system trajectories. Thus, CAS contain "no a priori assumptions about key variables, emphasize nonlinear causal effects between and within systems, and view system equilibrium as multiple, temporary, and moving" (Duit and Galaz 2008:312).

During the years that followed, the argument that social and ecological systems can be seen as interactive, linked systems was 
developed and strengthened by drawing on a comprehensive understanding of the characteristics and dynamics of CAS (Berkes and Folke 1998, Berkes et al. 2003, Gunderson and Holling 2002). Traditional conceptualizations in ecology ignored the fact that living systems operate under far-from-equilibrium conditions (Holling 1973, Prigogine and Stengers 1984) and viewed human systems only as external drivers of ecosystems, and conversely, economics and other social sciences generally viewed natural systems as nondynamic resources for extracting capital gains or providing the basis for livelihoods. The gradual conceptual development from separate environmental and human systems to an understanding of intertwined complex adaptive SES has changed how these relations and interactions are viewed and subsequently studied, modeled, and governed (Folke et al. 2005, Duit and Galaz 2008). The perception of SES as integrated systems has become the basis of a mainstream approach in the pursuit of addressing the challenges of navigating toward more just and sustainable futures for humanity and the Earth (Folke et al. 2011, 2016, Biggs et al. 2012, Levin et al. 2013, Fischer et al. 2015).

Although the shift from a system to a CAS understanding of SES occurred without significant disruption to the research field, this shift has introduced profound consequences for the theoretical and methodological assumptions that frame contemporary knowledge of SES. Before discussing these implications, we introduce a typology of six organizing principles that constitute the basic, generally agreed-upon attributes and features of CAS. We suggest that these organizing principles can help orientate and guide new scholars in the field of SES research in understanding the key features of CAS, as well as in identifying and developing appropriate methods and approaches for studying SES. We argue that this can help realize the potential of a complexity-based understanding of SES and thus, help address the pressing sustainability challenges of our time.

\section{TOWARD A CONCEPTUAL TYPOLOGY FOR CLASSIFYING THE UNDERLYING ORGANIZING PRINCIPLES OF CAS}

CAS-based research usually has at least two distinct ways of engaging with the notion of CAS: doing research from a CAS perspective (employing holistic or systemic theories or approaches in observing and intervening in specific areas of interest that appear to pose intractable or complex problems); or doing research into the nature of CAS (focusing on how CAS as phenomena in the world come into being and developing theories and methods that explain the attributes and nature of CAS). Investigating the nature of CAS involves gaining deeper insights into the underlying mechanisms that bring about CAS behavior and identifying the underlying causal explanations (Hammond 2017). We propose a general typology of six organizing principles that underlie the observable attributes and features of CAS to assist newcomers to the field of SES research in engaging with the notion of CAS, as well as to provide a basis for interrogating appropriate methods and approaches for studying SES.

Leading CAS authors (Table 1) have proposed a wide variety of CAS attributes. Although these contributions aim to highlight key features of CAS, it remains a challenge to judge which features are necessary and sufficient when choosing approaches and methods best suited to studying SES. Although definitions of
CAS attributes differ in terms of the selection and categorization of features, there are some important commonalities. All definitions point toward the fact that there are certain distinguishable properties of CAS that are only observable when viewed at a holistic systems level. These features are all examples of systemic properties that do not reside in individual elements or components of the systems. Moreover, the features identified in the literature aim to account for the defining properties that explain the behavior of CAS. This form of classification, often called descriptive or epistemological, is based on identifying features that describe phenomena according to salient structures (Gnoli and Poli 2004, Woermann 2016).

In the absence of a universally accepted definition or unified theory of CAS, we identified six underlying organizing principles through which the numerous different CAS attributes proposed in the literature can be categorized or clustered together (Table 2). The six principles provide a conceptual typology by which similar salient features, properties, and behaviors of CAS can be clustered together. The categorization is based on how the organizing principles are conceptualized to cause CAS features and attributes to come into being, in other words, how complexity is generated as a systems property. Table 2 identifies which epistemological features (i.e., the structures and causations that can be studied and observed in real-world CAS) as identified in Table 1, are associated with each organizing principle. The principles offer a heuristic framework for making sense of, for example, the diverse set of features listed in Table 1 (which is not an exhaustive list of attributes listed in CAS literature). We argue that such a conceptual typology can help organize our thinking about how to recognize and engage with SES as CAS. As a heuristic framework, the typology can be used to consolidate knowledge of the features of CAS and inform methods and approaches that depart from CAS-based perspectives. Moreover, it can facilitate greater integration of knowledge, methods, and practices that constitute the field of SES research.

The six organizing principles contribute to a general CAS-based ontology for observing and studying SES and include the following underlying causal explanations of CAS features: (1) CAS are constituted relationally; (2) CAS have adaptive capacities; (3) CAS behavior comes about as a result of dynamic processes; (4) CAS are radically open; (5) CAS are determined contextually; and (6) novel qualities emerge through complex causality. The classification is based on an ontological reading of CAS to discern general patterns and underlying causal explanations (Gnoli and Poli 2004). The principles listed in Table 2 , therefore, assume that the features and dynamics of CAS are a feature of the real world and not the result of our limited understanding of complex phenomena (Capra 2005, Poli 2013). Our conceptual classification aims to describe CAS in terms of a combination of their structure and causations (Poli and Seibt 2010). Structure includes the constituent parts (material and nonmaterial) as well as the forces that organize part-whole relations. Causations can be viewed as interactions that allow elements to act upon and influence one another. The six organizing principles are neither a new revised set of definitions of CAS, nor a new set of properties of observed (as opposed to modeled) systems or new normative guidelines concerning how SES should be analyzed. 
Table 1. Overview of prominent authors' classifications of complex adaptive systems (CAS) features, the characteristics they suggest for identifying CAS, and how these respective classifications have influenced social-ecological systems (SES) research.

\begin{tabular}{|c|c|c|c|c|}
\hline Author(s) & List of features & Rationale behind choice of features & Reference & $\begin{array}{l}\text { Examples of SES literature } \\
\text { that draws on this framing }\end{array}$ \\
\hline John Holland & $\begin{array}{l}\text { 1. Aggregation } \\
\text { 2. Nonlinearity } \\
\text { 3. Flows } \\
\text { 4. Diversity } \\
\text { 5. Tagging } \\
\text { 6. Internal models } \\
\text { 7. Building blocks }\end{array}$ & $\begin{array}{l}\text { - To explain how interconnected parts } \\
\text { can form a dynamic network with the } \\
\text { capacity to adapt in response to stimuli; } \\
\text { - To provide an overarching } \\
\text { explanatory model for conceptualizing } \\
\text { and modeling emergence. }\end{array}$ & (Holland 1995) & $\begin{array}{l}\text { (Norberg and Cumming } \\
\text { 2008, Cumming 2014) }\end{array}$ \\
\hline $\begin{array}{l}\text { W. Brian Arthur, } \\
\text { Steven Durlauf, } \\
\text { and David Lane }\end{array}$ & $\begin{array}{l}\text { 1. Dispersed interaction } \\
\text { 2. No global controller } \\
\text { 3. Cross-cutting hierarchical } \\
\text { organization } \\
\text { 4. Continual adaptation } \\
\text { 5. Perpetual novelty } \\
\text { 6. Out-of-equilibrium dynamics }\end{array}$ & $\begin{array}{l}\text { - To understand and study the economy } \\
\text { as being an "adaptive nonlinear } \\
\text { network" (following Holland 1995); } \\
\text { - To distinguish a complexity approach } \\
\text { that is distinct from both equilibrium } \\
\text { and dynamical systems approaches. }\end{array}$ & $\begin{array}{l}\text { (Arthur 1988, Arthur } \\
\text { et al. 1997) }\end{array}$ & $\begin{array}{l}\text { (Costanza et al. 1993, } \\
\text { Costanza 1996, Westley et } \\
\text { al. 2011) }\end{array}$ \\
\hline Simon Levin & $\begin{array}{l}\text { 1. Sustained diversity and } \\
\text { individuality of components } \\
\text { 2. Localized interactions among } \\
\text { components } \\
\text { 3. An autonomous process that } \\
\text { selects from among those } \\
\text { components, based on the results } \\
\text { of local interactions }\end{array}$ & $\begin{array}{l}\text { - To offer a more lenient definition of } \\
\text { what elements and mechanisms } \\
\text { compose CAS; } \\
\text { - To define and model CAS behaviour } \\
\text { by focusing on the mechanisms that } \\
\text { allow complicated structures and } \\
\text { patterns of interaction between } \\
\text { components to emerge. }\end{array}$ & (Levin 1998, 2005) & $\begin{array}{l}\text { (Holling 2001, Norberg } \\
\text { 2004, Levin et al. 2013, } \\
\text { Schoon and van der Leeuw } \\
\text { 2015, Hagstrom and Levin } \\
\text { 2017) }\end{array}$ \\
\hline Paul Cilliers & $\begin{array}{l}\text { 1. Large number of heterogeneous } \\
\text { components } \\
\text { 2. Dynamically interacting } \\
\text { components } \\
\text { 3. Rich interaction of components } \\
\text { 4. Nonlinear interaction } \\
\text { 5. Abundance of (nonlinear) } \\
\text { feedback routes } \\
\text { 6. No need for direct link for } \\
\text { interaction of distant elements } \\
\text { 7. Complex adaptive systems as } \\
\text { open systems } \\
\text { 8. Open systems operation under } \\
\text { conditions far from equilibrium } \\
\text { 9. Vitally important system history } \\
\text { 10. Subcomponents without access } \\
\text { to all the information in the system }\end{array}$ & $\begin{array}{l}\text { - To offer a more qualitative description } \\
\text { of CAS; } \\
\text { - To argue that the behavior of a } \\
\text { complex adaptive system as a whole is a } \\
\text { relational and emergent property; } \\
\text { - To help us make substantial claims } \\
\text { about the nature of complexity. }\end{array}$ & (Cilliers 1998) & $\begin{array}{l}\text { (Audouin et al. 2013, } \\
\text { Cilliers et al. 2013, Rogers } \\
\text { et al. 2013) }\end{array}$ \\
\hline $\begin{array}{l}\text { Dominique Chu, } \\
\text { Roger Strand, and } \\
\text { Ragnar Fjelland }\end{array}$ & $\begin{array}{l}\text { 1. Internal inhomogeneity of the } \\
\text { system } \\
\text { 2. Adaptivity of agents in the } \\
\text { system } \\
\text { 3. Nonlinear interactions between } \\
\text { parts of the system } \\
\text { 4. Net-like causal structure of the } \\
\text { system } \\
\text { 5. Radical openness } \\
\text { 6. Contextuality }\end{array}$ & $\begin{array}{l}\text { - To define common denominators of } \\
\text { CAS in terms of generators of } \\
\text { complexity; } \\
\text { - To focus more on properties of } \\
\text { complex systems, rather than the details } \\
\text { of mechanism; } \\
\text {-To encourage empirical investigations } \\
\text { into the presence and nature of radical } \\
\text { openness and contextuality. }\end{array}$ & (Chu et al. 2003) & $\begin{array}{l}\text { (Cilliers et al. 2013, Peter } \\
\text { and Swilling 2014) }\end{array}$ \\
\hline
\end{tabular}

\section{Principle 1: CAS are constituted relationally}

A distinctive feature of CAS is that they are defined more by the interactions among their constituent components than by the components themselves (Wimsatt 1994, Biggs et al. 2010, Kineman 2011, Nicholson and Dupré 2018). Relations can be defined as processes of engagement, as well as the outcomes of such processes. This implies that relations form the units of analysis in CAS. Thus, recognizing that CAS are constituted relationally acknowledges the fact that an element of a CAS is not so much a thing as a process (Hammond 2017). Moreover, the focus shifts to the nature of the relations between system elements, and the interactions that occur between a system and its wider environment. Relations shape and determine the structure and function of CAS; the process of becoming, rather than static states of being therefore distinguishes CAS. This understanding is based on insights from systems biology (Boogerd et al. 2007, Wolkenhauer and Muir 2011; Kauffman 2009, unpublished manuscript, https://arxiv.org/pdf/0907.2492.pdf) and 
Table 2. Conceptual typology of the general underlying organizing principles of complex adaptive system (CAS) features.

\begin{tabular}{|c|c|}
\hline Types of organizing principles that bring about CAS features & Related concepts and attributes that characterize CAS \\
\hline 1. Constituted relationally & $\begin{array}{l}\text { Netlike structure, hierarchies, holarchic, diverse components, built-in redundancy, } \\
\text { heterogeneity. }\end{array}$ \\
\hline 2. Adaptive capacities & $\begin{array}{l}\text { Self-generation, self-organization, decentralized control, memory, evolutionary and } \\
\text { concurrent persistence and change (resilience), anticipatory capacities. }\end{array}$ \\
\hline 3. Dynamic processes & $\begin{array}{l}\text { Far-from-equilibrium, multiple-trajectories possible, periods of fast and slow change } \\
\text { (punctuated equilibria), nonlinear interactions, attractors, thresholds, tipping points, } \\
\text { regime shifts, feedback loops (enabling and constraining), cross-scale interactions. }\end{array}$ \\
\hline 4. Radically open & $\begin{array}{l}\text { Porous boundaries, embeddedness, nestedness, exchange of matter, information, } \\
\text { energy, teleconnections. }\end{array}$ \\
\hline 5. Contextually determined & $\begin{array}{l}\text { Function changes as system changes, components with multiple context dependent } \\
\text { identities. }\end{array}$ \\
\hline 6. Novel qualities emerge through complex causality & $\begin{array}{l}\text { Circular/recursive causality, large webs of causality, multiple pathways of causality, } \\
\text { high levels of stochasticity, same starting conditions that produce different outcomes, } \\
\text { emergent properties. }\end{array}$ \\
\hline
\end{tabular}

process philosophy (Whitehead 1979, DeLanda 2006, Smith and Jenks 2006) as well as other systems disciplines (Morin 2008, Wells 2013, Boulton et al. 2015, Edson et al. 2017).

Relational networks do not constitute only material structures (Capra 2005), but are functional networks of relationships that come about as the result of interactive patterns of processes. Systems can also be connected to, or nested in, other systems, representing hierarchies of relations at different scales (Holland 1995, Cilliers 1998, Levin 1999). Recognizing that relations form networks of causal effects that are generative of complex structures and processes, implies that CAS are brought about through process-dependent interactions on multiple scales. These interactions allow CAS to self-organize and produce adaptive, dynamic, and emergent behavioral patterns (Folke 2006).

\section{Principle 2: CAS have adaptive capacities}

CAS adapt over time in response to feedbacks from interactions between system elements, and between elements and their environment. The connections between elements and how these relations give shape to the structure and function of a system are sustained by self-generating organizational capacities (Rosen 1991, Günther and Folke 1993, Morin 1999, Levin 2005, Fox Keller 2008). Different parts of a system are linked through patterns of organization that emerge in response to contextual changes in the system and its environment, giving the system the capacity to adapt to such changes. The history of how CAS evolve and adapt is captured in the systems' memory at various temporal and spatial scales and plays an important role in defining the state of the system as well as affecting its future trajectories (Cilliers 1998, Gunderson and Holling 2002).

\section{Principle 3: Dynamic processes generate CAS behavior}

The dynamic interactions that constitute CAS and their relations with the environment are nonlinear, which means that the magnitude of a system's outputs cannot be measured in direct proportionality to the magnitude of its causes (Prigogine and Stengers 1984, Holling 2001, Levin et al. 2013). A rich repertoire of systemic behavior is caused by nonlinear feedback loops that can either dampen or amplify perturbations both internally and between the system and its environment. Slow and fast variables are present and these form cross-scale, nonlinear, reinforcing, or negative feedbacks that allow multiple stable states to exist with various interlinked system-dependent thresholds. The notion of nonlinearity is, therefore, a precursor for unpredictability and uncertainty and thus, makes prediction and control of CAS particularly difficult (Gallopín et al. 2001, Carpenter et al. 2015).

\section{Principle 4: CAS are radically open}

From von Bertalanffy's description of living systems (von Bertalanffy 1968), we know that CAS are open systems. In other words, energy, information, and matter are exchanged between the system and its environment. However, defining the boundaries of CAS is not a trivial undertaking because CAS interact with their milieu in such a way that it becomes almost impossible to discern which components belong inside the system and which belong to the broader environment (Juarrero 2002, Chu et al. 2003, Cilliers 2008). Moreover, identifying a system (or establishing the boundary conditions) (Midgley and Pinzón 2011) is often a function of the perspective of the observer (Cilliers 2001). The boundary is permeable and allows for communication through a flow of energy and information between a system and its surroundings. Neither the nature nor the place of the boundary is easily determinable. This means that what happens within the boundaries of what observers deem to be CAS, invariably affects the milieu or broader environment through feedback loops or teleconnections (Schellnhuber 1999).

The concept of the Anthropocene is a good example of the notion of radical openness. Research on the Anthropocene has revealed that the biosphere does not simply form the backdrop upon which humans and all living organisms exist (Steffen et al. 2011). Human actions shape reality beyond their sphere of direct influence, affecting much larger systems and thus shaping the biosphere in numerous ways from local to global scales (Folke et al. 2016).

\section{Principle 5: CAS are contextually determined}

The internal structure of CAS emerges from patterns of dynamic interaction between system elements on the one hand, and between the elements and their wider environment, on the other. Unlike systems characterized by linear processes that can be effectively isolated from external influence, CAS have external structures or boundary conditions that are as much a part of the complex system as the internal structure (Juarrero and Lissack 2000, Cilliers 2001). As a result, CAS are context dependent and emerge as a result of relations that are defined by functions and 
Table 3. Differences between complicated systems and complex adaptive systems (based on Poli 2013).

\begin{tabular}{ll}
\hline \hline Complicated Systems & Complex Adaptive Systems \\
\hline $\begin{array}{l}\text { Causes can be individually distinguished in terms of linear cause-and- } \\
\text { effect pathways. }\end{array}$ & $\begin{array}{l}\text { No clearly distinguishable cause-and-effect pathways can be discerned because } \\
\text { behavioral patterns result from networks of multiple interacting causes; parts } \\
\text { are multiply-connected. } \\
\text { Outputs are not proportionally related to inputs; minor changes in a } \\
\text { For each input to the system there is a proportionate output. }\end{array}$ \\
$\begin{array}{l}\text { Structural parts and their functional relations can be decomposed } \\
\text { piece by piece. }\end{array}$ & $\begin{array}{l}\text { Structural parts are multifunctional; the same function can be performed by } \\
\text { different structural parts, therefore, the one-structure-one-function assumption } \\
\text { does not hold. }\end{array}$ \\
$\begin{array}{l}\text { Relevant systemic interactions can be controlled, and the problems } \\
\text { they present admit permanent solutions. }\end{array}$ & $\begin{array}{l}\text { Dynamic interactions are such that small inputs may result in disproportionate } \\
\text { effects that produce unintended consequences that lead to high levels of } \\
\text { surprise and uncertainty; any intervention changes the system and causes new } \\
\text { challenges. }\end{array}$ \\
\hline
\end{tabular}

contexts (Juarrero 1999). As the context changes, the system will change and elements in the system may take on a different role or function. A CAS and its components, therefore, have multiple context dependent identities (Chu et al. 2003, Zellmer et al. 2006). Moreover, these functions often conflict, triggering unintended consequences in the system's behavior. As a consequence, the function of a system can be restricted or enhanced by changing the environment in which it is embedded (Poli 2013).

Principle 6: Novel qualities emerge through complex causality Cause and effect interactions in CAS are not unidirectional or linear, but marked by complex recursive causal pathways (Rasch and Knodt 1994). System outputs can function as inputs, and small effects might have large causes and vice versa (Cilliers 1998). These emergent properties are exhibited by the system as a whole and cannot be attributed to the properties of individual components. Moreover, systems cannot be understood nor their behavior predicted on the sole basis of information relating to their individual parts (Heylighen et al. 2007, Cilliers 2008, Preiser and Cilliers 2010, Wells 2013, Capra and Luisi 2014, Hammond 2017). Emergent system properties trigger creativity, novelty, and evolution in CAS (Biggs et al. 2012, Montuori 2003, Poli 2013, Wells 2013). Owing to the relations in CAS, nonlinear effects not only have causal agency, but also result in cascading effects or "causal spread" (Wheeler and Clark 1999), when a particular phenomenon becomes unexpectedly dependent on causal factors that were initially deemed unrelated to it.

Emergent complex causality lies at the heart of the difference between complicated systems and CAS (Table 3). Complicated systems follow linear cause and effect processes of organization. As Poli (2013) argues, complicated systems can be analyzed through structural analysis, meaning that a particular system can be dismantled into its constituent parts. Behavioral effects can be traced back to material causes, and for each input into the system, there is a corresponding and proportionate output. Changes in the behavior of complicated systems can be measured and modeled through formal equations, as well as compared through statistical relations between the variables that describe these systems. Problems that emerge from multiple interacting relations in CAS are difficult to distinguish individually and the challenges they present cannot be definitively solved. Interventions can have disproportionately small or large effects and frequently generate new problems as a result of unintended consequences of the intervention (Allenby and Sarewitz 2011, Poli 2013). CAS are, therefore, qualitatively different to complicated systems, and not simply extreme forms of these, as summarized in Table 3 (Poli 2013)

These six organizing principles form the foundation for conceptualizing a CAS-based ontology and offer an alternative to that of Newtonian metaphysics by giving ontological legitimacy to the relations and emergent, nonlinear organizing processes that constitute CAS. Ontological complexity implies that emergent properties and patterns of behavior are real and do not exist independently from the parts or agents that constitute these phenomena (Casti 1997, Preiser and Cilliers 2010). A complexity-based ontology recognizes both the functional and relational dependency between structurally integrated components of the system and the systemic environment or context. The properties of CAS come about and change because of the interplay between the adaptive responses of the components, the emergent properties of the whole, and the context in which they operate. Simultaneous bottom-up, top-down, multilevel interactions between different spatial, as well as temporal scales, result in the codetermination of CAS structures and patterns of behavior that emerge over time (Levin et al. 2013).

\section{IMPLICATIONS FOR SOCIAL-ECOLOGICAL SYSTEMS RESEARCH APPROACHES AND METHODS}

Understanding the nature of SES as CAS poses new frontiers for studying, governing, and influencing SES (Biggs et al. 2015b, Bodin 2017, Österblom et al. 2017). Because our knowledge of SES is partial and diverges over time, the best strategy for developing an integrated understanding of SES is to explore a variety of models that span a broad spectrum of methodologies and disciplinary divides (Cilliers 2002, Poli 2013, Tengö et al. 2014). A CAS-based epistemology comprises a range of scientific theories and frameworks (Chapman 2016) that can describe, unpack, and confirm the complex features and dynamics of CAS. Therefore, researchers should use methods of inquiry and knowledge-generating practices that draw from a plurality of relevant epistemologies and frameworks (Mitchell 2004, Tengö et al. 2014, Reyers et al. 2015).

We suggest that studying and engaging with SES as CAS offers the following three key implications: (1) a shift in terms of what should be studied and considered during any framing or analysis 
of SES; (2) knowing that the nature of reality is complex has real consequences for how we choose methods and practical approaches when observing and studying intertwined socialecological relations; and (3) engagement with SES as CAS poses certain practical and normative challenges.

\section{Shifting the focus of study}

Observation of systemic behavior in CAS calls for exploring and experimenting with conceptual and practical tools that enable a shift in the focus of study (Capra and Luisi 2014):

- From characteristics of parts to systemic properties: This involves a shift from studying the characteristics of parts in isolation to looking at systemic properties that emerge from the underlying patterns of organization. Systemic properties are destroyed when dissected (Rosen 1991) because emergent properties cannot be decomposed into the properties of their constituent parts.

- From objects to relations: Systems properties emerge through dynamic patterns of interaction. Thus, the underlying organizational processes, connections, and emergent behavioral patterns are important to understand (Juarrero 2002).

- From closed to open systems: Complex phenomena are embedded in networks and hierarchies through which there is a continuous exchange of information, energy, and material. Therefore, there is no clear inside or outside of SES because all entities are connected through processes of organization on different spatial and temporal scales.

- From measuring to capturing and assessing complexity: Complex phenomena are constituted relationally through dynamic interactions that form emergent patterns of behavior. Thus, a perceptual shift is necessary that enables us to capture and understand relationships (Capra and Luisi 2014) that cannot be measured in terms of material causes. Moreover, through the dynamic mapping and assessing of relations, connections, and multiple complex causal pathways, we can trace configurations and characterize networks, cycles, and cross-scale interactions. These efforts can elucidate how SES are constituted relationally and how patterns of behavior emerge. This can in turn facilitate our ability to anticipate adaptive and transformative behavior and pathways.

- From observation to intervention: CAS are contextualized and constituted relationally, and information about systems properties and dynamics cannot be separated from the organizational properties defining a system. The study of SES implies a process of framing the boundaries of the system that is observer-dependent and entails intervention that is quite different from that of objective observation (Cilliers 2002, Midgley and Richardson 2007).

\section{Choice of methods and practical approaches for studying SES} Knowing that the nature of reality is complex has real consequences for how we choose methods and practical approaches for observing, analyzing, and modeling real-world, intertwined social-ecological relations. In fact, a CAS-based approach introduces a different way of thinking about the world and how to understand our place in it. Although it does not provide us with a foolproof, best-practice manual for how to design research projects or change interventions (Preiser and Cilliers 2010), CAS-based thinking does provide some general premises that may reduce the tendencies toward oversimplifying reality, or analyzing systems in ways that generate misleading conclusions.

To produce empirically valid and meaningful data and interpretations of the diversity of the features and properties of SES, we need to expose and understand the underlying causal relationships, patterns, and processes that generate systemic behavior, patterns, and events that govern anthropogenic and nonanthropogenic drivers and social-ecological conditions (Capra 2005, Österblom et al. 2013). Deciding which methods and models are appropriate is not obvious, and choices are often made on subjective grounds such as experience, usefulness, or even intuition (Mingers 2000, Audouin et al. 2013, Cilliers et al. 2013).

Based on the six organizing principles identified in this paper, we have identified key implications for choosing CAS-based approaches and methods (Table 4), and compared these with potential research methods and approaches that seem suited to addressing the implications of these assumptions. This list of methods is not complete. This comparison of methods and approaches in terms of their organizing principles can help orientate students and researchers to suitable methods for research into SES properties. It also helps to point to the kind of methodological innovations needed to advance our understanding of SES and the features and mechanisms that produce systemic properties, patterns, and dynamics. Based on the implications of the six organizing principles, the following practical considerations should guide any study of SES as CAS:

- The nature and structure of relationships between components in a system has to be considered explicitly;

- Systems adapt and change, and this should be anticipated, even if not easily predicted;

- Systems behavior is amplified or dampened by feedback loops that can lead to tipping points, regime shifts, and feedback structures;

- SES are inherently unpredictable and deeply uncertain;

- External variables could have important influences on a system's behavior but cannot be included in the model;

- System components have multiple functions that change when context changes;

- Cause-and-effect interactions cannot be traced in linear and isolated causal trajectories.

\section{Engagement with CAS poses certain normative challenges}

There is no stepping outside of complexity and thus, there is no framework of frameworks that can claim objective engagement. Any engagement with CAS is based on the act of choosing a specific entry point, framework, or approach. This choice does not need to be arbitrary in any way, but the status of the framework (and the framework itself) should not be used as the basis for making claims about knowledge as being truly objective (Ulrich 1994, Midgley 2003, Preiser and Cilliers 2010, Woermann and Cilliers 2012). As the context in which a particular framework 
Table 4. Key implications of the six organizing principles for choosing potential complex adaptive systems (CAS)-based methods and approaches.

\begin{tabular}{ll}
\hline \hline $\begin{array}{l}\text { Organizing principles that } \\
\text { bring about CAS features }\end{array}$ & $\begin{array}{l}\text { Implications for choosing CAS-based methods and } \\
\text { approaches }\end{array}$ \\
\hline 1. Constituted relationally & $\begin{array}{l}\text { The nature and structure of relationships between } \\
\text { components in a system have to be considered explicitly; }\end{array}$
\end{tabular}

ponents in a system have to be considered explicitly;

Considerations for potential methods and research approaches

- Establish the nature of relations and structure of

Collaboration depends strongly on the structure of social networks and connectivities by means of relational system analyses;

networks and the flow of information within them;

- Foster trust and collaboration across a variety of networks;

Diversity is key and allows for different kinds of

- Support communication platforms to maintain connectivity and interaction; interactions to take place.

- Create integrative frameworks and methods to assess relations and connectivity;

- Assess and capture heterogeneity and redundancy.

Examples: network analysis, agent-based modeling, diverse spatial analysis techniques (particularly connectivity analysis), participatory systems analysis, mental modeling, Bayesian belief networks, fuzzy cognitive maps, social-ecological inventories.

2. Adaptive

Over time, the structures and functions of systems change;

Multiple modes of reorganization are possible when systems undergo change;

- Guard against rigid planning and strategy design and implement adaptive comanagement practices that foster iterative learning and participatory collaborative processes of engagement;

- Cultivate social and embedded learning experiences;

Adaptive capacity results from a system's ability to learn and have memory;

Change happens through adaptation, evolution, and transformation;

Control is not located in one isolated element of the system, but spread throughout the nodes and relations of the system.

3. Dynamic

System behavior is amplified or dampened by feedback loops, and can lead to tipping points and regimes shifts;

Feedback structures are responsible for the changes we experience over time;

Structures and processes are also linked across scales;

CAS are inherently unpredictable and deeply uncertain.

External variables could have important influences on system behavior but cannot be included in the models of the system;

Projects and geographical locations are not closed and isolated entities;

Systems create and maintain their own boundaries that do not separate but intimately connect the system with its environment;

Any modeled system is embedded in a larger system;

Unknown variables could have important influences on system behavior;

Expect uncertainty and surprise.
- Support capacities that allow for self-organizing processes;

- Develop holistic frameworks that favor synthesis rather than analysis

- Foster responses that are flexible in redefining outcomes as necessary;

- Assess resilience and anticipate possible future organizational patterns and pathways.

Examples: functional type mapping, simulations, scenario development, adaptive object modeling, causal loop modeling

- Map systemic feedbacks across different spatial and temporal scales;

- Assess which mechanisms build or inhibit systemic agency and resilience;

- Identify systemic thresholds, traps, and indicators that could help detect possible regime shifts;

- Expect surprise and unintended consequences when intervening in CAS;

- Capture spatial and temporal cross-scale dynamics

- Investigate thresholds and tipping points.

Examples: systems dynamic modeling, agent-based modeling, Bayesian belief networks, time series analysis.

- Show awareness that the project will influence and shape systems and realities that are situated outside of the scope of the project's aims and objectives;

- Assess teleconnections and the effects of the flow of energy, matter, and information to demonstrate how systems are embedded in other systems;

- Construct system boundaries by means of the modeling process whilst knowing that we cannot assume that external connections do not affect the system under observation.

Examples: anticipatory future studies methods (horizon scanning, bottom-up scenarios, back-casting), historical reconstruction methods, qualitative comparative case study analysis, participatory mapping, institutional analysis. 
5. Contextual

All CAS are context dependent;

Systemic components have multiple functions that change when the context changes;

Context is not a passive backdrop to a system, but an active agent in itself, which enables or inhibits systemic agency;

Context itself has agency in shaping meaning.
- Foster iterative processes of meaning-making that facilitate dialogue to include multiple perspectives from a wide range of stakeholders;

- Use multiple-evidence based data sources to cocreate and integrate knowledge bases;

- Develop provisional frameworks that are context dependent and can be reworked when contexts change;

- Build capacity to navigate and understand multiple and contested normative agendas;

- Explore participatory research methods where research is embedded in fostering knowledge cocreation;

- Develop and use games to simulate and anticipate multiple different outcomes and system trajectories.

Examples: transdisciplinary research methods, participatory action research, case studies, participatory games, participatory mapping, participant observation, climate simulation games, telemetry.

- Engage methods that can illustrate a better understanding of emergent and unexpected phenomena; - Explore causes that may have multiple starting points and pathways:

- Anticipate alternative future pathways and innovations by engaging scenarios and future foresight approaches.

Wicked problems cannot be solved in a piecemeal way; any intervention will result in unintended consequences;

Adoption of a complexity-based frame of mind in considering innovative practice and new decision possibilities.
Examples: adaptive management, adaptive governance, participatory narrative inquiry, dialogue workshops, participant observation, social-ecological experiments. is to be used changes, it should be revised to integrate understanding and experiences gained.

Knowledge of CAS in a given moment in time is, therefore, provisional and calls for modesty both in terms of the frameworks and models used. At the same time, CAS knowledge has the transformational potential to expose exploitative and overly confident conventional disciplinary regimes and practices (Ulrich 1994, Holling et al. 1998, Cilliers 2005a, Midgley and Richardson 2007, Rajagopalan and Midgley 2015) while offering voice and agency to alternative knowledge streams (Tengö et al. 2014). Because CAS thinking does not provide access to a fixed, objective position from where we can impose values and moral principles, we need new normative constellations (Forst 2011) that are cognizant of how humans and nature are constituted relationally (Folke et al. 2016). This entails accepting that our decisions are based on partial knowledge, and also means that potentially adverse outcomes might occur as a result of our inability to know everything. It also acknowledges that responsibility cannot be removed from the researcher when making judgements and choices about approaches and methods to use when addressing problem situations, to ensure the best possible exploration or intervention (Cilliers 2005b, Preiser et al. 2017).

Conventional theories of change and transformation often suggest that interventions can be made from an objective position in the management and control of system trajectories. Traditional research approaches seek to understand the world in order to be better able to predict and control a volatile and uncertain external environment and in doing so, assume an objective or detached position in relation to the phenomena under observation. This assumption of objectivity marginalizes considerations of values and subjective experience (Hammond 2005). From a CAS-based perspective, it is problematic to make truth claims from such assumptions (Rogers et al. 2013). Systemic change seldom comes about by following rules and regulations in a programmatic way, but can best be anticipated when reflected upon. This often involves participatory approaches, as well as collaborative governance strategies to navigate the surprise and uncertainty that may result (Carpenter et al. 2009, Folke et al. 2016).

Engaging with real-world problems from a CAS-based perspective does not favor or call for practices or approaches founded on constructivist worldviews that propagate relativism. In fact, the contrary is the case. The argument against relativism is grounded in the observation that CAS are not chaotic systems. For a system to have meaning, it needs structure and organizing processes that result in recognizable patterns of behavior which, in turn, exert certain constraints on the system. Rules or norms are examples of such constraints, but these are enabling constraints that allow for interaction. If there were no rules or norms, societies or systems would fall apart. Thus, constraints are related to both the structure and function of a CAS and the enabling capacities and contexts in which it exists and develops (Cilliers 1998). Norms are, in fact, the result of complex and dynamic interactions and constitute context-sensitive constraints that enable us to act. Such an understanding of normative agency does not commit us to either relativism or random choice because all positions or models are not equally acceptable (Preiser and Cilliers 2010, Woermann and Cilliers 2012).

CAS-based approaches provide guidelines to proceed differently in this world and call for more inclusive and integrative modes of engaging with real-world problems that are cognizant of how human well-being is embedded in the biosphere. The call to engage in biosphere-based sustainability science (Folke et al. 2016) 
therefore introduces an ethical imperative to create novel forms of collaborative agency and alternative moral constructs. For example, the concept of interdependence should become a central component of any decision-making framework informing sustainable development interventions. Actively implementing strategies that favor the integration of nature, society, and technology should become a core social norm in policy-making debates. Participatory and collaborative multistakeholder processes that foster dialogue and knowledge cocreation and the development of more systemic awareness among the members of different communities should be encouraged above top-down decision-making processes (Hammond 2005). These practices should be based on the recognition of the relational interdependencies of SES in navigating action and decisionmaking processes in the Anthropocene.

\section{CONCLUSION}

Researchers and practitioners are challenged to explore new avenues for studying and engaging with SES in ways that can contribute to addressing pressing sustainability challenges of our time. The gap that remains between models of the world and the world as it is (undisclosed), and our ability to engage with SES in ways that bring about meaningful change, should inspire creativity in problem solving endeavors. Given that it is not possible to develop best-practice manuals that contain rule-based formulas for dealing with complexity, the encounter with complex adaptive SES leaves us in a space where we are beckoned to respond and act in ways that allow for rigorous and novel conceptual framings. In addition, we are called to search for practical tools that can deepen our understanding of the rapidly changing and intertwined social-ecological dynamics of the Anthropocene.

In this paper, we have proposed a typology of six organizing principles that capture the underlying assumptions of a CAS ontology. An awareness of the fundamental interdependence of all phenomena that are embedded in the cyclical processes of living systems has significant implications for how the relations between social and ecological systems are conceptualized (Folke et al. 2002, 2016, McAlpine et al. 2015). A complexity-based ontology stops us from seeing humans as positioned outside or above nature, which is only valued in terms of its usefulness to social systems. Instead, humans are seen to be fundamentally embedded in natural systems and to profoundly affect the Earth system and its biosphere (Steffen et al. 2011, 2015). Examples of emergent properties in real-world systems are the following: poverty in social and economic systems; food insecurity in agricultural and economic systems; and compromised immunity in human biological systems.

A CAS-based ontology suggests that the relation between social and ecological systems are conceptualized as linked and thus as inseparable ontological entities. They can also be conceptualized as intricate assemblages (DeLanda 2006) of connections or intertwined, complex, and adaptive SES (Folke et al. 2016). This emphasizes the inevitable connectivity and interdependencies of causal networks that are marked by a constant movement of conjunction and merging together to form a generic state of causal structures characterizing the intertwined nature of SES.

SES are multiply connected through material and nonmaterial or functional processes in which the same constellation can have many different components and dynamics working toward stabilizing the system. At the same time, other interactions will be forcing the system to change or even transform its identity (or capacities) into a different constellation (DeLanda 2006). In fact, the same agent may simultaneously participate in opposing processes by exercising different sets of capacities or values. Complex adaptive SES are liminal phenomena and thus, the process of identifying any constellation of intertwined interactions that are context-dependent and expandable at any level or scale is always the product of being embedded in the complex web of relations that link knower and known (Cilliers 1998, Hammond 2005).

A fundamental understanding of SES as CAS allows us to engage and develop theoretical and methodological orientations that are cognizant of the organizing principles underlying the generation of the complex patterns and dynamics in real-world SES. The six organizing principles we propose provide a conceptual typology of key CAS features that can be used as a heuristic framework to help orientate researchers, practitioners, and decision makers in choosing appropriate research methods and approaches suited to the study of the specific properties, features, and mechanisms of real-world SES challenges. It also highlights the need for further research into understanding the assumptions, implications, and methodological challenges the six organizing principles pose for studying SES. SES research methods grounded in CAS-based approaches will not provide fool-proof strategies that can be utilized blindly in the search for answers to difficult questions (Ostrom 2007). However, we hope that synthesizing the core features of CAS and unpacking their implications for what we choose to study, the types of methods and approaches we use, and the normative frameworks we adopt, will assist researchers, policy makers, and practitioners to undertake research and interventions that can help navigate the uncertainties of the Anthropocene toward more resilient and sustainable futures.

${ }^{[1]}$ See Brian Castellani's mapping of the network of concepts and
fields of study that is shaping the complexity paradigm: http://
www.art-sciencefactory.com/complexity-map feb09.html

Responses to this article can be read online at: http://www.ecologyandsociety.org/issues/responses. php/10558

\section{Acknowledgments:}

This work is supported by the Guidance for Resilience in the Anthropocene: Investments for Development (GRAID) project funded by the Swedish International Development Agency (Sida) hosted at Stockholm Resilience Centre, Sweden. Reinette Biggs is also supported by the South African Research Chairs Initiative (SARChI) of the Department of Science and Technology and National Research Foundation of South Africa (grant 98766); and a Young Researchers Grant from the Vetenskapsrådet in Sweden (grant 621-2014-5137). We thank Maureen Klos for editing assistance and three anonymous reviewers for their helpful comments on earlier drafts. 


\section{LITERATURE CITED}

Alhadeff-Jones, M. 2013. Complexity, methodology and method: crafting a critical process of research. Complicity: An International Journal of Complexity and Education 10(1/2):19-44. http://cepa.info/920

Allenby, B., and D. Sarewitz. 2011. The techno-human condition. MIT Press, Cambridge, Massachusetts, USA.

Arthur, W. B. 1988. Self-reinforcing mechanisms in economics. Pages 9-31 in P. W. Anderson, K. J. Arrow, and D. Pines, editors. The economy as an evolving complex system. Adisson Wesley, Redwood City, California, USA. http://dx.doi.org/10.1201/9780$\underline{429492846-2}$

Arthur, W. B. 1999. Complexity and the economy. Science 284 (5411):107-110. http://dx.doi.org/10.1126/science.284.5411.107

Arthur, W. B., S. Durlauf, and D. Lane. 1997. Introduction. Pages 1-14 in W. B. Arthur, S. N. Durlauf, and D. Lane, editors. The economy as an evolving complex system II. Addison-Wesley, Reading, Massachusetts, USA.

Audouin, M., R. Preiser, S. Nienaber, L. Downsborough, J. Lanz, and S. Mavengahama. 2013. Exploring the implications of critical complexity for the study of social-ecological systems. Ecology and Society 18(3):12. http://dx.doi.org/10.5751/ES-05434-180312

Bateson, G. 1979. Mind and nature. A necessary unity. E. P. Dutton, New York, New York, USA.

Berkes, F., J. Colding, and C. Folke. 2003. Navigating socialecological systems: building resilience for complexity and change. Cambridge University Press, Cambridge, UK. http://dx.doi. org/10.1017/CBO9780511541957

Berkes, F., and C. Folke. 1998. Linking social and ecological systems. Cambridge University Press, Cambridge, UK.

Biggs, R., C. Rhode, S. Archibald, L. M. Kunene, S. S. Mutanga, N. Nkuna, P. O. Ocholla, and L. J. Phadima. 2015b. Strategies for managing complex social-ecological systems in the face of uncertainty: examples from South Africa and beyond. Ecology and Society 20(1):52. http://dx.doi.org/10.5751/ES-07380-200152

Biggs, R., M. Schlüter, D. Biggs, E. L. Bohensky, S. BurnSilver, G. Cundill, V. Dakos, T. M. Daw, L. S. Evans, K. Kotschy, A. M. Leitch, C. Meek, A. Quinlan, C. Raudsepp-Hearne, M. D. Robards, M. L. Schoon, L. Schultz, and P. C. West. 2012. Toward principles for enhancing the resilience of ecosystem services. Annual Review of Environment and Resources 37(1):421-448. http://dx.doi.org/10.1146/annurev-environ-051211-123836

Biggs, R., M. Schlüter, and M. L. Schoon. 2015a. Principles for building resilience: sustaining ecosystem services in socialecological systems. Cambridge University Press, Cambridge, UK. http://dx.doi.org/10.1017/CBO9781316014240

Biggs, R., F. R. Westley, and S. R. Carpenter. 2010. Navigating the back loop: fostering social innovation and transformation in ecosystem management. Ecology and Society 15(2):9. http://dx. doi.org/10.5751/ES-03411-150209

Binder, C. R., J. Hinkel, P. W. G. Bots, and C. Pahl-Wostl. 2013. Comparison of frameworks for analyzing social-ecological systems. Ecology and Society 18(4):26. http://dx.doi.org/10.5751/ ES-05551-180426
Bodin, Ö. 2017. Collaborative environmental governance: achieving collective action in social-ecological systems. Science 357(6352). http://dx.doi.org/10.1126/science.aan1114

Bodin, Ö., and M. Tengö. 2012. Disentangling intangible socialecological systems. Global Environmental Change 22(2):430-439. http://dx.doi.org/10.1016/j.gloenvcha.2012.01.005

Boogerd, F. C., F. J. Bruggeman, J. H. S. Hofmeyr, and H. V. Westerhoff. 2007. Towards philosophical foundations of systems biology: introduction. Pages 3-19 in F. C. Boogerd, F. J. Bruggeman, J.-H. S. Hofmeyr, and H. V. Westerhoff, editors. Systems biology: philosophical foundations. Elsevier, Amsterdam, The Netherlands. http://dx.doi.org/10.1016/B978-044452085-2/50003-6

Boulton, J. G., P. M. Allen, and C. Bowman. 2015. Embracing complexity: strategic perspectives for an age of turbulence. Oxford University Press, Oxford, UK. http://dx.doi.org/10.1093/acprof: oso/9780199565252.001.0001

Cairney, P. 2012. Complexity theory in political science and public policy. Political Studies Review 10(3):346-358. http://dx.doi. org/10.1111/j.1478-9302.2012.00270.x

Capra, F. 2005. Complexity and life. Theory, Culture \& Society 22(5):33-44. http://dx.doi.org/10.1177/0263276405057046

Capra, F., and P. L. Luisi. 2014. The systems view of life. Cambridge University Press, Cambridge, UK. http://dx.doi. org/10.1017/CBO9780511895555

Carpenter, S. R. 2003. Regime shifts in lake ecosystems: pattern and variation. Volume 15. Excellence in Ecology Series, Ecology Institute, Oldendorf/Luhe, Germany.

Carpenter, S. R., C. Folke, M. Scheffer, and F. R. Westley. 2009. Resilience: accounting for the noncomputable. Ecology and Society 14(1):13. http://dx.doi.org/10.5751/ES-02819-140113

Carpenter, S. R., W. A. Brock, C. Folke, E. H. van Nes, and M. Scheffer. 2015. Allowing variance may enlarge the safe operating space for exploited ecosystems. Proceedings of the National Academy of Sciences 112(46):14384-14389. http://dx.doi. org/10.1073/pnas.1511804112

Carpenter, S. R., C. Folke, A. Norström, O. Olsson, L. Schultz, B. Agarwal, P. Balvanera, B. Campbell, J. C. Castilla, W. Cramer, R. DeFries, P. Eyzaguirre, T. P. Hughes, S. Polasky, Z. Sanusi, R. Scholes, and M. Spierenburg. 2012. Program on ecosystem change and society: an international research strategy for integrated social-ecological systems. Current Opinion in Environmental Sustainability 4(1):134-138. http://dx.doi.org/10.1016/j.cosust.2012.01.001

Casti, J. 1997. Would-be worlds. John Wiley \& Sons, New York, New York, USA.

Chapman, K. 2016. Complexity and creative capacity. Routledge, Taylor \& Francis Group, London, UK. http://dx.doi. org/10.4324/9781315680767

Chu, D., R. Strand, and R. Fjelland. 2003. Theories of complexity: common denominators of complex systems. Complexity 8(3):19-30. http://dx.doi.org/10.1002/cplx.10059

Cilliers, P. 1998. Complexity and postmodernism: understanding complex systems. Routledge, London, UK. 
Cilliers, P. 2001. Boundaries, hierarchies and networks in complex systems. International Journal of Innovation Management 5 (2):135-147. http://dx.doi.org/10.1142/S1363919601000312

Cilliers, P. 2002. Why we cannot know complex things completely. Emergence 4(1):77-84. http://dx.doi.org/10.1080/15213250.2002.9687736

Cilliers, P. 2005a. Complexity, deconstruction and relativism. Theory, Culture \& Society 22(5):255-267. http://dx.doi. org/10.1177/0263276405058052

Cilliers, P. 2005b. Knowledge, limits and boundaries. Futures 37 (7):605-613. http://dx.doi.org/10.1016/j.futures.2004.11.001

Cilliers, P. 2008. Complexity theory as a general framework for sustainability science. Pages 39-57 in M. Burns and A. Weaver, editors. Exploring sustainability science. A Southern African perspective. African SUN MeDIA, Stellenbosch, South Africa.

Cilliers, P., H. C. Biggs, S. Blignaut, A. G. Choles, J. S. Hofmeyr, G. P. W. Jewitt, and D. J. Roux. 2013. Complexity, modeling, and natural resource management. Ecology and Society 18(3):1. http:// dx.doi.org/10.5751/ES-05382-180301

Costanza, R. 1996. Ecological economics: reintegrating the study of humans and nature. Ecological Applications 6(4):978-990. http://dx.doi.org/10.2307/2269581

Costanza, R., L. Wainger, C. Folke, and K.-G. Mäler. 1993. Modeling complex ecological economic systems: toward an evolutionary, dynamic understanding of people and nature. BioScience 43:545-555. http://dx.doi.org/10.2307/1311949

Crepin, A.-S., R. Biggs, S. Polasky, M. Troell, and A. de Zeeuw. 2012. Regime shifts and management. Ecological Economics 84:15-22. http://dx.doi.org/10.1016/j.ecolecon.2012.09.003

Cumming, G. S. 2014. Theoretical frameworks for the analysis of social-ecological systems. Pages 3-24 in S. Sakai and C. Umetsu, editors. Social-ecological systems in transition. Springer Japan, Tokyo, Japan. http://dx.doi.org/10.1007/978-4-431-54910-9 1

DeLanda, M. 2006. A new philosophy of society: assemblage theory and social complexity. Continuum, London, UK.

Díaz, S., S. Demissew, J. Carabias, C. Joly, M. Lonsdale, N. Ash, A. Larigauderie, J. R. Adhikari, S. Arico, A. Báldi, A. Bartuska, I. A. Baste, A. Bilgin, E. Brondizio, K. M. A. Chan, V. E. Figueroa, A. Duraiappah, M. Fischer, R. Hill, T. Koetz, P. Leadley, P. Lyver, G. M. Mace, B. Martin-Lopez, M. Okumura, D. Pacheco, U. Pascual, E. S. Pérez, B. Reyers, E. Roth, O. Saito, R. J. Scholes, N. Sharma, H. Tallis, R. Thaman, R. Watson, T. Yahara, Z. A. Hamid, C. Akosim, Y. Al-Hafedh, R. Allahverdiyev, E. Amankwah, T. S. Asah, Z. Asfaw, G. Bartus, A. L. Brooks, J. Caillaux, G. Dalle, D. Darnaedi, A. Driver, G. Erpul, P. EscobarEyzaguirre, P. Failler, A. M. M. Fouda, B. Fu, H. Gundimeda, S. Hashimoto, F. Homer, S. Lavorel, G. Lichtenstein, W. A. Mala, W. Mandivenyi, P. Matczak, C. Mbizvo, M. Mehrdadi, J. P. Metzger, J. B. Mikissa, H. Moller, H. A. Mooney, P. Mumby, H. Nagendra, C. Nesshover, A. A. Oteng-Yeboah, G. Pataki, M. Roué, J. Rubis, M. Schultz, P. Smith, R. Sumaila, K. Takeuchi, S. Thomas, M. Verma, Y. Yeo-Chang, and D. Zlatanova. 2015. The IPBES conceptual framework - connecting nature and people. Current Opinion in Environmental Sustainability 14:1-16. http:// dx.doi.org/10.1016/j.cosust.2014.11.002
Díaz, S., J. Fargione, F. S. Chapin III, and D. Tilman. 2006. Biodiversity loss threatens human well-being. PLoS Biology 4(8): e277. http://dx.doi.org/10.1371/journal.pbio.0040277

Duit, A., and V. Galaz. 2008. Governance and complexityemerging issues for governance theory. Governance 21(3):311-335. http://dx.doi.org/10.1111/j.1468-0491.2008.00402.x

Edson, M. C., P. Buckle, H. Shankar, and S. Editors. 2017. A guide to systems research philosophy, processes and practice. Springer Science \& Business Media, Singapore.

Fischer, J., T. A. Gardner, E. M. Bennett, P. Balvanera, R. Biggs, S. Carpenter, T. Daw, C. Folke, R. Hill, T. P. Hughes, T. Luthe, M. Maass, M. Meacham, A. V Norström, G. Peterson, C. Queiroz, R. Seppelt, M. Spierenburg, and J. Tenhunen. 2015. Advancing sustainability through mainstreaming a socialecological systems perspective. Current Opinion in Environmental Sustainability 14:144-149. http://dx.doi.org/10.1016/j.cosust.2015.06.002

Folke, C. 2006. Resilience: the emergence of a perspective for social-ecological systems analyses. Global Environmental Change 16(3):253-267. http://dx.doi.org/10.1016/j.gloenvcha.2006.04.002

Folke, C. 2016. Resilience (Republished). Ecology and Society 21 (4):44. http://dx.doi.org/10.5751/ES-09088-210444

Folke, C., R. Biggs, A. V. Norström, B. Reyers, and J. Rockström. 2016. Social-ecological resilience and biosphere-based sustainability science. Ecology and Society 21(3):41. http://dx.doi.org/10.5751/ ES-08748-210341

Folke, C., S. Carpenter, T. Elmqvist, L. Gunderson, C. S. Holling, and B. Walker. 2002. Resilience and sustainable development: building adaptive capacity in a world of transformations. Ambio 31(5):437-440. http://dx.doi.org/10.1579/0044-7447-31.5.437

Folke, C., S. Carpenter, B. Walker, M. Scheffer, T. Elmqvist, L. Gunderson, and C. S. Holling. 2004. Regime shifts, resilience, and biodiversity in ecosystem management. Annual Review of Ecology, Evolution, and Systematics 35:557-581. http://dx.doi. org/10.1146/annurev.ecolsys.35.021103.105711

Folke, C., T. Hahn, P. Olsson, and J. Norberg. 2005. Adaptive governance of social-ecological systems. Annual Review of Environment and Resources 30(1):441-473. http://dx.doi. org/10.1146/annurev.energy.30.050504.144511

Folke, C., Å. Jansson, J. Rockström, P. Olsson, S. R. Carpenter, F. S. Chapin III, A.-S. Crépin, G. Daily, K. Danell, J. Ebbesson, T. Elmqvist, V. Galaz, F. Moberg, M. Nilsson, H. Österblom, E. Ostrom, A. Persson, G. Peterson, S. Polasky, W. Steffen, B. Walker, and F. Westley. 2011. Reconnecting to the Biosphere. Ambio 40 (7):719-738. http://dx.doi.org/10.1007/s13280-011-0184-y

Forst, R. 2011. Die Herausbildung normativer Ordnungen: Interdisziplinäre Perspektiven. Campus, Frankfurt am Main, Germany.

Fox Keller, E. 2008. Organisms, machines, and thunderstorms: a history of self-organization, Part One. Historical Studies in the Natural Sciences 38(1):45-75. http://dx.doi.org/10.1525/hsns.2008.38.1.45

Gallopín, G. C., S. Funtowicz, M. O'Connor, and J. Ravetz. 2001. Science for the twenty-first century: from social contract to the scientific core. International Social Science Journal 53 (168):219-229. http://dx.doi.org/10.1111/1468-2451.00311 
Gnoli, C., and R. Poli. 2004. Levels of reality and levels of representation. Knowledge Organization 31(3):151-160.

Günther, F., and C. Folke. 1993. Characteristics of nested living systems. Journal of Biological Systems 1(3):257-274. http://dx.doi. org/10.1142/S0218339093000173

Gunderson, L. H., and C. S. Holling. 2002. Panarchy: understanding transformations in human and natural systems. Island Press, Washington, D.C., USA.

Hagstrom, G. I., and S. A. Levin. 2017. Marine ecosystems as complex adaptive systems: emergent patterns, critical transitions, and public goods. Ecosystems 20(3):458-476. http://dx.doi. org/10.1007/s10021-017-0114-3

Haider, L. J., J. Hentati-Sundberg, M. Giusti, J. Goodness, M. Hamann, V. A. Masterson, M. Meacham, A. Merrie, D. Ospina, C. Schill, and H. Sinare. 2018. The undisciplinary journey: earlycareer perspectives in sustainability science. Sustainability Science 13(1):191-204. http://dx.doi.org/10.1007/s11625-017-0445-1

Hammond, D. 2005. Philosophical and ethical foundations of systems thinking. tripleC 3(2):20-27. http://dx.doi.org/10.31269/ triplec.v3i2.20

Hammond, D. 2017. Philosophical foundations of systems research. Pages 1-19 in M. C. Edson, P. Buckle Henning, and S. Sankaran, editors. A guide to systems research: philosophy, processes and practice. Springer Science \& Business Media, Singapore. http://dx.doi.org/10.1007/978-981-10-0263-2_1

Hartvigsen, G., A. Kinzig, and G. Peterson. 1998. Complex adaptive systems: use and analysis of complex adaptive systems in ecosystem science: overview of special section. Ecosystems 1 (5):427-430. http://dx.doi.org/10.1007/s100219900036

Heylighen, F., P. Cilliers, and C. Gershenson. 2007. Philosophy and complexity. Pages 117-134 in R. Bogg and J. Geyer, editor. Complexity, science and society. Radcliffe, Oxford, UK. http://dx. doi.org/10.1201/9781315383132-8

Holland, J. 1995. Hidden order: how adaptation builds complexity. Addison-Wesley, Reading, Massachusetts, USA.

Holling, C. S. 1973. Resilience and stability of ecological systems. Annual Review of Ecology and Systematics 4:1-23. http://dx.doi. org/10.1146/annurev.es.04.110173.000245

Holling, C. S. 2001. Understanding the complexity of economic, ecological, and social systems. Ecosystems 4(5):390-405. http:// dx.doi.org/10.1007/s10021-001-0101-5

Holling, C. S., F. Berkes, and C. Folke. 1998. Science, sustainability and resource management. Pages 342-362 in F. Berkes and C. Folke, editors. Linking social and ecological systems: management practices and social mechanisms for building resilience. Cambridge University Press, Cambridge, UK.

Hughes, T. P., S. R. Carpenter, J. Rockström, M. Scheffer, and B. Walker. 2013. Multiscale regime shifts and planetary boundaries. Trends in Ecology \& Evolution 28(7):389-395. http://dx.doi. org/10.1016/J.TREE.2013.05.019

Jörg, T. 2017. On reinventing education in the age of complexity approach. Complicity: An International Journal of Complexity and Education 14(2):30-53.
Juarrero, A. 1999. Dynamics in action: intentional behavior as a complex system. MIT Press, Cambridge, Massachusetts, USA.

Juarrero, A. 2002. Complex dynamical systems and the problem of identify. Emergence 4(1/2):94-104. http://dx.doi. org/10.1080/15213250.2002.9687738

Juarrero, A., and M. Lissack. 2000. Dynamics in action: intentional behavior as a complex system. Emergence: Complexity \& Organization 2(2):24-57. http://dx.doi.org/10.1215/00318108-110-3-469

Kineman, J. J. 2011. Relational science: a synthesis. Axiomathes 21(3):393-437. http://dx.doi.org/10.1007/s10516-011-9154-Z

Levin, S. A. 1998. Ecosystems and the biosphere as complex adaptive systems. Ecosystems 1(5):431-436. http://dx.doi. org/10.1007/s100219900037

Levin, S. A. 1999. Fragile dominion: complexity and the commons. Perseus Books, Reading, Massachusetts, USA.

Levin, S. 2005. Self-organization and the emergence of complexity in ecological systems. BioScience 55(12):1075-1079. http://dx.doi. org/10.1641/0006-3568(2005)055[1075:SATEOC]2.0.CO;2

Levin, S. A., T. Xepapadeas, A.-S. Crépin, J. Norberg, A. de Zeeuw, C. Folke, T. Hughes, K. Arrow, S. Barrett, G. Daily, P. Ehrlich, N. Kautsky, K.-G. Mäler, S. Polasky, M. Troell, J. R. Vincent, and B. Walker. 2013. Social-ecological systems as complex adaptive systems: modeling and policy implications. Environment and Development Economics 18(02):111-132. http:// dx.doi.org/10.1017/S1355770X12000460

Liu, J., T. Dietz, S. R. Carpenter, M. Alberti, C. Folke, E. Moran, A. N. Pell, P. Deadman, T. Kratz, J. Lubchenco, E. Ostrom, Z. Ouyang, W. Provencher, C. L. Redman, S. H. Schneider, and W. W. Taylor. 2007. Complexity of coupled human and natural systems. Science 317(5844):1513-1516. http://dx.doi.org/10.1126/ science. 1144004

McAlpine, C. A., L. M. Seabrook, J. G. Ryan, B. J. Feeney, W. J. Ripple, A. H. Ehrlich, and P. R. Ehrlich. 2015. Transformational change: creating a safe operating space for humanity. Ecology and Society 20(1):56. http://dx.doi.org/10.5751/ES-07181-200156

Meadows, D. H. 2008. Thinking in systems. Earthscan, London, UK.

Midgley, G. 2003. Science as systemic intervention: some implications of systems thinking and complexity for the philosophy of science. Systemic Practice and Action Research 16 (2):77-97. http://dx.doi.org/10.1023/A:1022833409353

Midgley, G. 2006. Systemic intervention for public health. American Journal of Public Health 96(3):466-472. http://dx.doi. org/10.2105/AJPH.2005.067660

Midgley, G., and L. A. Pinzón. 2011. Boundary critique and its implications for conflict prevention. Journal of the Operational Research Society 62(8):1543-1554. http://dx.doi.org/10.1057/ jors. 2010.76

Midgley, G., and K. A. Richardson. 2007. Systems thinking for community involvement in policy analysis. Emergence: Complexity and Organization (E: CO) 9(1/2):167-183. 
Milne, B. T. 1998. Motivations and benefits of complex systems approaches in ecology. Ecosystems 1:449-456. http://dx.doi. org/10.1007/s100219900040

Mingers, J. 2000. The contribution of critical realism as an underpinning philosophy for OR/MS and systems. Journal of the Operational Research Society 51(11):1256-1270. http://dx.doi. org/10.1057/palgrave.jors.2601033

Mitchell, S. 2004. Why integrative pluralism? E: CO Emergence: Complexity and Organization 6(Special Double Issue):81-91.

Montuori, A. 2003. The complexity of improvisation and the improvisation of complexity: social science, art and creativity. Human Relations 56(2):237-255. http://dx.doi.org/10.1177/0018$\underline{726703056002893}$

Morin, E. 1999. Organization and complexity. Annals of the New York Academy of Sciences 879:115-121. http://dx.doi. org/10.1111/j.1749-6632.1999.tb10410.x

Morin, E. 2008. On complexity. Hampton, Cresskill, New Jersey, USA.

Nicholson, D. J., and J. Dupré. 2018. Everything flows: towards a processual philosophy of biology. Oxford University Press, Oxford, UK. http://dx.doi.org/10.1093/oso/9780198779636.001.0001

Norberg, J. 2004. Biodiversity and ecosystem functioning: a complex adaptive systems approach. Limnology and Oceanography 49(4part2):1269-1277. http://dx.doi.org/10.4319/10.2004.49.4_part_2.1269

Norberg, J., and G. S. Cumming, editors. 2008. Complexity theory for a sustainable future. Columbia University Press, New York, New York, USA.

Österblom, H., B. I. Crona, C. Folke, M. Nyström, and M. Troell. 2017. Marine ecosystem science on an intertwined planet. Ecosystems 20(1):54-61. http://dx.doi.org/10.1007/s10021-016-9998-6

Österblom, H., A. Merrie, M. Metian, W. J. Boonstra, T. Blenckner, J. R. Watson, R. R. Rykaczewski, Y. Ota, J. L. Sarmiento, V. Christensen, M. Schlüter, S. Birnbaum, B. G. Gustafsson, C. Humborg, C.-M. Mörth, B. Müller-Karulis, M. T. Tomczak, M. Troell, and C. Folke. 2013. Modeling socialecological scenarios in marine systems. BioScience 63(9):735-744. http://dx.doi.org/10.1525/bio.2013.63.9.9

Ostrom, E. 2007. A diagnostic approach for going beyond panaceas. Proceedings of the National Academy of Sciences of the United States of America 104(39):15181-15187. http://dx.doi. org/10.1073/pnas.0702288104

Ostrom, E. 2009. A general framework for analyzing sustainability of social-ecological systems. Science 325 (5939):419-422. http://dx.doi.org/10.1126/science.1172133

Peter, C., and M. Swilling. 2014. Linking complexity and sustainability theories: implications for modeling sustainability transitions. Sustainability 6(3):1594-1622. http://dx.doi.org/10.3390/ $\underline{\text { su6031594 }}$

Poli, R. 2013. A note on the difference between complicated and complex social systems. Cadmus 2(1):142-147.

Poli, R., and J. Seibt, editors. 2010. Theory and applications of ontology. Springer, Dordrecht, The Netherlands. [online] URL: https://www.springer.com/gp/book/9789048188444
Preiser, R., and P. Cilliers. 2010. Unpacking the ethics of complexity: concluding reflections. Pages 265-287 in P. Cilliers and R. Preiser, editors. Complexity, difference and identity. Springer, Dordrecht, The Netherlands. http://dx.doi. org/10.1007/978-90-481-9187-1 13

Preiser, R., L. M. Pereira, and R. (O.) Biggs. 2017. Navigating alternative framings of human-environment interactions: variations on the theme of 'Finding Nemo.' Anthropocene 20:83-87. http://dx.doi.org/10.1016/J.ANCENE.2017.10.003

Prigogine, I., and I. Stengers. 1984. Order out of chaos: man's new dialogue with nature. Bantam, New York, New York, USA.

Rajagopalan, R., and G. Midgley. 2015. Knowing differently in systemic intervention. Systems Research and Behavioral Science 32(5):546-561. http://dx.doi.org/10.1002/sres. 2352

Rasch, W. 1991. Theories of complexity, complexities of theory: Habermas, Luhmann, and the study of social systems. German Studies Review 14(1):65-83. http://dx.doi.org/10.2307/1430154

Rasch, W., and E. M. Knodt. 1994. Systems theory and the system of theory. New German Critique 61:3-7. http://dx.doi. org/10.2307/488617

Reyers, B., C. Folke, M.-L. Moore, R. Biggs, and V. Galaz. 2018. Social-ecological systems insights for navigating the dynamics of the Anthropocene. Annual Review of Environment and Resources 43:267-289. http://dx.doi.org/10.1146/annurev-environ-110615-085349

Reyers, B., J. L. Nel, P. J. O'Farrell, N. Sitas, and D. C. Nel. 2015. Navigating complexity through knowledge coproduction: mainstreaming ecosystem services into disaster risk reduction. Proceedings of the National Academy of Sciences 112 (24):7362-7368. http://dx.doi.org/10.1073/pnas.1414374112

Rockström, J. 2016. Future Earth. Science 351(6271):319. http:// dx.doi.org/10.1126/science.aaf2138

Rogers, K. H., R. Luton, H. Biggs, R. Biggs, S. Blignaut, A. G. Choles, C. G. Palmer, and P. Tangwe. 2013. Fostering complexity thinking in action research for change in social-ecological systems. Ecology and Society 18(2):31. http://dx.doi.org/10.5751/ ES-05330-180231

Rosen, R. 1991. Life itself: a comprehensive enquiry into the nature, origin, and fabrication of life. Columbia University Press, New York, New York, USA.

Scheffer, M., S. R. Carpenter, T. M. Lenton, J. Bascompte, W. Brock, V. Dakos, J. van de Koppel, I. A. van de Leemput, S. A. Levin, E. H. van Nes, M. Pascual, and J. Vandermeer. 2012. Anticipating critical transitions. Science 338(6105):344-348. http://dx.doi.org/10.1126/science.1225244

Schellnhuber, H. J. 1999. 'Earth system' analysis and the second Copernican revolution. Nature 402:C19-C23. http://dx.doi. org/10.1038/35011515

Schlüter, M., J. Hinkel, P. W. G. Bots, and R. Arlinghaus. 2014. Application of the SES framework for model-based analysis of the dynamics of social-ecological systems. Ecology and Society 19(1):36. http://dx.doi.org/10.5751/ES-05782-190136

Schoon, M., and S. van der Leeuw. 2015. The shift toward socialecological systems perspectives: insights into the human-nature 
relationship. Natures Sciences Sociétés 23(2):166-174. http://dx. doi.org/10.1051/nss/2015034

Smith, J., and C. Jenks. 2006. Qualitative complexity: ecology, cognitive processes and the re-emergence of structures in posthumanist social theory. Routledge, Taylor \& Francis Group, London, UK. http://dx.doi.org/10.4324/9780203366837

Steffen, W., W. Broadgate, L. Deutsch, O. Gaffney, and C. Ludwig. 2015. The trajectory of the Anthropocene: The Great Acceleration. Anthropocene Review 2(1):81-98. http://dx.doi. org/10.1177/2053019614564785

Steffen, W., Å. Persson, L. Deutsch, J. Zalasiewicz, M. Williams, K. Richardson, C. Crumley, P. Crutzen, C. Folke, L. Gordon, M. Molina, V. Ramanathan, J. Rockström, M. Scheffer, H. J. Schellnhuber, and U. Svedin. 2011. The Anthropocene: from global change to planetary stewardship. Ambio 40(7):739-761. http://dx.doi.org/10.1007/s13280-011-0185-x

Steffen, W., J. Rockström, K. Richardson, T. M. Lenton, C. Folke, D. Liverman, C. P. Summerhayes, A. D. Barnosky, S. E. Cornell, M. Crucifix, J. F. Donges, I. Fetzer, S. J. Lade, M. Scheffer, R. Winkelmann, and H. J. Schellnhuber. 2018. Trajectories of the Earth system in the Anthropocene. Proceedings of the National Academy of Sciences 115(33):8252-8259. http://dx.doi.org/10.1073/ pnas. 1810141115

Summers, J. K., L. M. Smith, J. L. Case, and R. A. Linthurst. 2012. A review of the elements of human well-being with an emphasis on the contribution of ecosystem services. Ambio 41 (4):327-340. http://dx.doi.org/10.1007/s13280-012-0256-7

Tengö, M., E. S. Brondizio, T. Elmqvist, P. Malmer, and M. Spierenburg. 2014. Connecting diverse knowledge systems for enhanced ecosystem governance: the multiple evidence base approach. Ambio 43(5):579-591. http://dx.doi.org/10.1007/ $\underline{\mathrm{s} 13280-014-0501-3}$

Thrift, N. 1999. The place of complexity. Theory, Culture \& Society 16(3):31-69. http://dx.doi.org/10.1177/02632769922050610

Ulrich, W. 1994. Can we secure future-responsive management through systems thinking and design? Interfaces 24(4):26-37. http://dx.doi.org/10.1287/inte.24.4.26

Urry, J. 2005. The complexity turn. Theory, Culture \& Society 22 (5):1-14. http://dx.doi.org/10.1177/0263276405057188

von Bertalanffy, L. 1968. General system theory: foundations, development, applications. George Braziller, New York, New York, USA.

Walker, B. H., L. H. Gunderson, A. P. Kinzig, C. Folke, S. R. Carpenter, and L. Schultz. 2006. A handful of heuristics and some propositions for understanding resilience in social-ecological systems. Ecology and Society 11(1):13. http://www.ecologyandsociety. org/vol11/iss1/art13/ http://dx.doi.org/10.5751/ES-01530-110113

Walker, B., C. S. Holling, S. R. Carpenter, and A. Kinzig. 2004. Resilience, adaptability and transformability in social-ecological systems. Ecology and Society 9(2):5. http://dx.doi.org/10.5751/ ES-00650-090205

Wells, J. 2013. Complexity and sustainability. Routledge, New York, New York, USA. http://dx.doi.org/10.4324/9780203095676
Westley, F., P. Olsson, C. Folke, T. Homer-Dixon, H. Vredenburg, D. Loorbach, J. Thompson, M. Nilsson, E. Lambin, J. Sendzimir, B. Banerjee, V. Galaz, and S. van der Leeuw. 2011. Tipping toward sustainability: emerging pathways of transformation. Ambio 40 (7):762-780. http://dx.doi.org/10.1007/s13280-011-0186-9

Wheeler, M., and A. Clark. 1999. Genic representation: reconciling content and causal complexity. British Journal for the Philosophy of Science 50(1):103-135. http://dx.doi.org/10.1093/ bjps/50.1.103

Whitehead, A. N. 1979. Process and reality. Free Press, Detroit, Michigan, USA.

Wimsatt, W. C. 1994. The ontology of complex systems: levels of organization, perspectives, and causal thickets. Canadian Journal of Philosophy 24(sup1):207-274. http://dx.doi.org/10.1080/0045$\underline{5091.1994 .10717400}$

Woermann, M. 2016. Bridging complexity and post-structuralism: insights and implications. Springer, Switzerland. http://dx.doi. org/10.1007/978-3-319-39047-5

Woermann, M., and P. Cilliers. 2012. The ethics of complexity and the complexity of ethics. South African Journal of Philosophy 31(2):447-463. http://dx.doi.org/10.1080/02580136.2012.10751787

Wolkenhauer, O., and A. Muir. 2011. The complexity of cellbiological systems. Pages 355-385 in C. Hooker, editor. Philosophy of complex systems. Volume 10. Handbook of the Philosophy of Science. Elsevier, Amsterdam, The Netherlands. http://dx.doi. org/10.1016/B978-0-444-52076-0.50013-4

Wu, J. 2013. Landscape sustainability science: ecosystem services and human well-being in changing landscapes. Landscape Ecology 28(6):999-1023. http://dx.doi.org/10.1007/s10980-013-9894-9

Zellmer, A. J., T. F. H. Allen, and K. Kesseboehmer. 2006. The nature of ecological complexity: a protocol for building the narrative. Ecological Complexity 3(3):171-182. http://dx.doi org/10.1016/j.ecocom.2006.06.002 